\title{
Beneficial Reuse and Sustainability: The Fate of Organic Compounds in Land-Applied Waste
}

\author{
Michael Overcash, Ronald C. Sims,* Judith L. Sims, and J. Karl C. Nieman
}

\begin{abstract}
Land application systems, also referred to as beneficial reuse systems, are engineered systems that have defined and permitted application areas based on site and waste characteristics to determine the land area size requirement. These terrestrial systems have orders of magnitude greater microbial capability and residence time to achieve decomposition and assimilation compared with aquatic systems. In this paper we focus on current information and information needs related to terrestrial fate pathways in land treatment systems. Attention is given to conventional organic chemicals as well as new estrogenic and pharmaceutical chemicals of commerce. Specific terrestrial fate pathways addressed include: decomposition, bound residue formation, leaching, runoff, and crop uptake. Molecular decomposition and formation of bound residues provide the basis for the design and regulation of land treatment systems. These mechanisms allow for assimilation of wastes and nondegradation of the environment and accomplish the goal of sustainable land use. Bound residues that are biologically produced are relatively immobile, degrade at rates similar to natural soil materials, and should present a significantly reduced risk to the environment as opposed to parent contaminants. With regard to leaching and runoff pathways, no comprehensive summary or mathematical model of organic chemical migration from land treatment systems has been developed. For the crop uptake pathway, a critical need exists to develop information for nonagricultural chemicals and to address full-scale performance and monitoring at more land application sites. The limited technology choices for treatment of biosolids, liquids, and other wastes implies that acceptance of some risks and occurrence of some benefits will continue to characterize land application practices that contribute directly to the goal of beneficial reuse and sustainability.
\end{abstract}

$\mathrm{O}$ RGANIC CHEMICALS are an integral part of our global environment and are present in all environmental media, including every level of the atmosphere, in surface and ground waters, and in the terrestrial environment (plants and soils). It is within this large-scale universe of organic chemicals that we must better understand the behavior of anthropogenic organic chemicals that affect human and ecological health and especially the behavior of those chemicals found in industrial and domestic waste sources. The goals of waste management are to protect the aesthetics and human and ecological health of terrestrial and aquatic systems that receive a variety of wastes including animal wastes, agricultural wastes, biosolids, industrial wastes, and municipal and/or

M. Overcash, Chemical Engineering Department, North Carolina State University, Raleigh, NC 27695. R.C. Sims and J.L. Sims, Department of Biological \& Irrigation Engineering, Utah State University, 4105 Old Main Hill, Logan, UT 84322-4105. J.K.C. Nieman, Utah Water Research Laboratory, Utah State University, 8200 Old Main Hill, Logan, UT 84322-8200. Received 15 Mar. 2004. *Corresponding author (rcsims@cc.usu.edu).

Published in J. Environ. Qual. 34:29-41 (2005).

(c) ASA, CSSA, SSSA

677 S. Segoe Rd., Madison, WI 53711 USA industrial effluents. By understanding and managing the behavior of organic chemicals introduced into the environment via waste disposal, it is possible to obtain the goal of beneficial reuse of organic wastes while protecting human health and the environment.

Land application systems, also referred to as beneficial reuse systems, are engineered systems that have defined application areas and permits for operations, based on site and waste characteristics that determine the land limiting constituent (Overcash and Pal, 1979). A land application system is generally located on an adequately drained soil with at least $1 \mathrm{~m}$ or more of soil separation above the seasonal high water table, is vegetated, and lacks unfavorable site characteristics such as karst areas, previous contamination, abandoned wells or bore holes, or excessive slopes.

Wastes that can be applied in land application systems include:

- industrial biosolids and/or effluents,

- animal waste,

- municipal effluent,

- municipal biosolids, and

- compost or other biosolids pretreatments.

Land application is also successfully used for the treatment and beneficial reuse of sediments taken from harbors in industrial and rural areas in the Netherlands, with estimates that up to 250 million $\mathrm{m}^{3}$ of sediments will be land-applied by the year 2010 (Harmsen, 2004).

In this review, we do not include the following types of terrestrial-based treatment:

- overland flow and rapid infiltration, both of which fulfill specific needs at certain sites (for a review of organics behavior of organic chemicals in these systems, see P. Fox, www.eas.asu.edu/civil/ncsws/ publications.html);

- land reclamation; or

- bioremediation of contaminated soils (Adriano et al., 1999)

Organic chemicals in these other terrestrial/waste systems also represent important environmental issues, but were not the topic of the Sustainable Land Application Conference.

One of the more common concerns about the presence of organic chemicals in land treatment systems arises from the known behavior of organic chemicals in aquatic (fresh and saline) systems, which are monitored more frequently because of their potential use as drinking water sources. Some recent examples of organic chemicals of concern in aquatic environments are brominated diphe-

Abbreviations: LLC, land limiting constituent; $\mathrm{PAH}$, polycyclic aromatic hydrocarbon; PCB, polychlorinated biphenyl. 
Table 1. Comparison of assimilative characteristics of organic chemicals in aquatic and terrestrial environments.

\begin{tabular}{|c|c|c|}
\hline \multirow[b]{2}{*}{ Parameter } & \multicolumn{2}{|c|}{ Environment } \\
\hline & Aquatic (streams, rivers, etc.) & Terrestrial (beneficial reuse sites) \\
\hline Organic carbon content & $4 \mathrm{mg} \mathrm{C} \mathrm{L}^{-1}$ water & $40000 \mathrm{mg} \mathrm{C} \mathrm{kg-1}$ soil \\
\hline Microbial populations & $\begin{array}{l}1 \times 10^{7} \text { cells } \mathrm{L}^{-1} \text { (eutrophication effects if } \\
\text { populations dramatically increase) }\end{array}$ & $\begin{array}{l}1 \times 10^{12} \text { cells } L^{-1} \text { (little effect if these } \\
\text { populations increase dramatically) }\end{array}$ \\
\hline $\begin{array}{l}\text { Residence time } \\
\text { Significant pathways }\end{array}$ & $\begin{array}{l}\text { approximately } 1 \text { to } 20 \mathrm{~d} \\
\text { microbial decomposition } \\
\text { abiotic reactions } \\
\text { photolysis } \\
\text { small to moderate sorption } \\
\text { moderate to low oxygen transfer to the } \\
\text { liquid phase }\end{array}$ & $\begin{array}{l}\text { years to decades } \\
\text { microbial decomposition } \\
\text { abiotic reactions } \\
\text { phytoremediation } \\
\text { substantial sorption } \\
\text { highly buffered } \\
\text { high oxygen transfer to the soil gas phase }\end{array}$ \\
\hline
\end{tabular}

nyl ethers (Hale et al., 2003), n-nitrosodimethylamine (Christen, 2003), perchlorate (Waldman, 2003), and endocrine disrupting chemicals (Andersen et al., 2003; Hanselman et al., 2003). The sources of these organic chemicals include wastewater treatment plants (WWTP), agricultural wastes such as broiler litter (Finlay-Moore et al., 2000), and animal feedlots (Addison, 1997). These organic chemicals were found to be toxic or persistent in aquatic environments, and thus their presence in landapplied wastes is a cause for concern.

A comparison between WWTP-aquatic systems and the terrestrial systems involved with beneficial reuse is shown in Table 1. These data indicate that microbial capability and residence times to achieve decomposition are orders of magnitude greater in a terrestrial beneficial reuse system than in an aquatic system. In addition, the toxic and carcinogenic properties may be different when the chemicals are present in a waste and soil environment rather than in an aquatic environment. For example, phenol in aquatic systems is labeled toxic at 0.001 to $0.2 \mathrm{mg} \mathrm{L}^{-1}$, while an aqueous phenol concentration of $200 \mathrm{mg} \mathrm{L}^{-1}$ in a simulated land treatment system had no apparent toxic effect on soil microorganisms (Amornprasertsook and Polprasert, 1996). Because of the capacity of land-based systems to buffer the potential toxic effects of waste-associated organic contaminants and to contribute to their assimilation into the soil system, the majority of studies conclude that they pose little or no risk to the environment when applied appropriately
(Naylor and Loehr, 1982; Webber and Lesage, 1989; Couillard and Grenier, 1990; Tischler et al., 1995; Dietrich et al., 1993; Bechmann and Grunewald, 1995; Webber and Wang, 1995; Lue-Hing et al., 1997; Center for Environmental Analysis, 2002). Additional information about the toxicity, carcinogenicity, and mutagenicity of specific organic chemicals in soil systems is needed to allow for better assessment of potential risks and for proper resource allocation to reduce those risks.

Contamination of ground water with organic chemicals from a variety of terrestrial activities is common and well documented. The potential for migration of specific organic chemicals through significant soil distances $(>1-2 \mathrm{~m})$ is related to a number of factors, including levels of naturally occurring organic matter, soil texture, the history of the receiver site, physicochemical properties of the organic compound, and the chemical concentrations in the system. As shown in Table 2, there are differences in the concentrations of organic chemicals applied during various land use activities, with concentrations of specific organic chemicals associated with beneficial reuse practices (i.e., a municipal biosolids land treatment system or a municipal effluent low rate irrigation system) being among the lowest. Other studies have also found that concentrations of organic contaminants including dioxins, dibenzofurans, polycyclic aromatic hydrocarbons, and polychlorinated biphenyls are relatively low in composts and sludges (Webber and Lesage, 1989; Houot et al., 2002; USEPA, 2002).

Table 2. Comparison of chemical loading to soil area of various land use practices. Chemical loading is given in $\mathrm{kg} \mathrm{ha}^{-1}$.

\begin{tabular}{|c|c|c|c|c|c|c|c|c|c|}
\hline \multirow[b]{2}{*}{ Parameter } & \multicolumn{9}{|c|}{ Land use } \\
\hline & $\begin{array}{c}\text { Old town } \\
\text { gasifier } \\
\text { contaminated } \\
\text { sites } \\
\end{array}$ & $\begin{array}{l}\text { Municipal } \\
\text { refuse } \\
\text { landfill }\end{array}$ & $\begin{array}{c}\text { Refinery } \\
\text { solid waste } \\
\text { landfill }\end{array}$ & $\begin{array}{l}\text { Petroleum } \\
\text { hazardous } \\
\text { waste land } \\
\text { treatment } \\
\text { site } \dagger\end{array}$ & $\begin{array}{l}\text { Septic } \\
\text { tank } \dagger\end{array}$ & $\begin{array}{l}\text { Municipal } \\
\text { biosolids } \\
\text { land } \\
\text { treatment } \\
\text { system } \dagger\end{array}$ & $\begin{array}{c}\text { Municipal } \\
\text { effluent low } \\
\text { rate irrigation } \\
\text { system } \dagger\end{array}$ & $\begin{array}{l}\text { Agricultural } \\
\text { chemicals } \\
\text { applications } \dagger\end{array}$ & $\begin{array}{c}\text { Natural } \\
\text { soils } \\
\end{array}$ \\
\hline Chemical oxygen demand & & $1.3 \times 10^{9}$ & & & $2.5 \times 10^{4}$ & $2.5 \times 10^{3}$ & $1 \times 10^{3}$ & & \\
\hline Total Kjeldahl nitrogen & & $0.8 \times 10^{6}$ & & $1 \times 10^{3}$ & $2 \times 10^{3}$ & $1.2 \times 10^{2}$ & $4 \times 10^{2}$ & & \\
\hline Total organic carbon & $1 \times 10^{11}$ & $0.5 \times 10^{9}$ & & $2 \times 10^{5}$ & & $5 \times 10^{2}$ & & & \\
\hline Copper & & $8 \times 10^{4}$ & $1.3 \times 10^{5}$ & & 5 & 2.5 & $4 \times 10^{-1}$ & & \\
\hline Zinc & & $3 \times 10^{5}$ & $1.3 \times 10^{5}$ & $\mathbf{1} \times \mathbf{1 0}^{2}$ & $6 \times 10^{1}$ & 5.4 & 1.4 & & \\
\hline Nickel & & $3 \times 10^{4}$ & $2.6 \times 10^{5}$ & $\mathbf{2} \times \mathbf{1 0}^{1}$ & & $5 \times 10^{-1}$ & $6 \times 10^{-1}$ & & \\
\hline Phenols & $1.4 \times 10^{10}$ & & $1.3 \times 10^{5}$ & $2 \times 10^{1}$ & $1 \times 10^{-1}$ & $5.5 \times 10^{-2}$ & $2 \times 10^{2}$ & & 1 \\
\hline Bis-2-ethyl hexyl phthalate & & & & & & 3 & $2 \times 10^{-1}$ & & \\
\hline $\operatorname{Benzo}(a)$ pyrene & $1.5 \times 10^{9}$ & & & & & $4 \times 10^{-3}$ & $1.5 \times 10^{-1}$ & & \\
\hline Naphthalenes & $6 \times 10^{10}$ & & & & & & & & \\
\hline $\begin{array}{l}\text { Total polycyclic aromatic } \\
\text { hydrocarbons (PAHs) }\end{array}$ & $6 \times 10^{10}$ & & & $2 \times 10^{3}$ & & $3 \times 10^{-2}$ & $1.8 \times 10^{-1}$ & & 3 \\
\hline $\begin{array}{l}\text { Polychlorinated biphenyls } \\
\text { (PCBs) }\end{array}$ & & & & & & $1.4 \times 10^{-2}$ & & & \\
\hline Herbicides and pesticides & & & & & & $5 \times \mathbf{1 0}^{-2}$ & $1.4 \times 10^{-1}$ & 1-2 & \\
\hline
\end{tabular}

$\dagger$ Indicates $\mathbf{k g ~ h a}^{-1} \mathbf{y r}^{-1}$. 
The European Union has produced a document that proposes limit values for concentration of organic compounds in sludge for use on land for certain classes of compounds (European Union, 2000). These are referred to as "AOX," the sum of halogenated organic compounds, including linear alkylbenzene sulfonates (LAS), di-2-ethylhexylphthalate (BEHP), nonylphenol ethoxylates (NPE), polycyclic aromatic hydrocarbons (PAHs), polychlorinated biphenyls (PCBs), and polychlorinated dibenzo- $p$-dioxins and -furans (PCDD/Fs). Kevin Jones' research group conducted a survey of digested sludge from 14 United Kingdom wastewater treatment plants to assess whether UK sludge was likely to comply with sludge limits for PCBs and PAHs proposed by the European Union (Stevens et al., 2003). While PAH concentrations would exceed the proposed EU limit of $6 \mathrm{mg}$ $\mathrm{kg}^{-1}, \mathrm{PCB}$ concentrations were below the EU limit of $0.8 \mathrm{mg} \mathrm{kg}^{-1}$.

Trace amounts of antibiotic organic chemicals have been found in soils resulting from biosolids application in Switzerland (Golet et al., 2003), while some potential endocrine disrupting compounds have also been found at higher than trace concentrations (Lee and Peart, 2002). The presence of polybrominated diphenyl ethers (PBDEs) in surface soils in the United Kingdom and Norway was investigated by the research team including Kevin Jones. Concentrations between 65 and $12000 \mathrm{ng} \mathrm{kg}^{-1}$ were found originating from industrial deposition and not from land application (Hassanin et al., 2004). In saturated soils produced by rainwater or waste leachate (such as those beneath leaking underground storage tanks or near unlined or leaking unlined landfills), many organic chemicals may potentially migrate. However, under the generally unsaturated soil conditions associated with periodic moist-dry cycles of beneficial reuse systems, migration is attenuated or eliminated. This potential for a land treatment system to retain contaminants of concern promotes contaminant assimilation.

There are numerous pathways in a land treatment system that account for the behavior and assimilation of organic chemicals applied during beneficial reuse practices (Brown et al., 1983; Loehr et al., 1979; Overcash and Pal, 1979; Smith et al., 2001). The number of pathways depends on the definition of pathways, for example binding to the soil organic matrix may be defined as rapid adsorption or as intermediate diffusionsorption, depending on the rate, or also considered as long-term residue behavior. Smith et al. (2001) consid- ered fate pathways of PAHs for the application of sewage sludge to pasture grass in the United Kingdom that included volatilization, rain-induced runoff, dilution of PAHs in grass due to growth of new grass, and potential for transfer into the food chain through grazing animals. A selection of case studies and characteristics of agricultural, industrial, and municipal by-products with regard to soil interactions and land application is presented in Power et al. (2000). In this paper, we focus on organic chemicals and the environmental pathways used in the design, operation, and monitoring of land application beneficial reuse systems, and simplify the number of pathways to include decomposition, bound residue formation, leaching, runoff, and crop uptake.

The land limiting constituent (LLC) approach is central to the design and sustainable operation of land treatment systems (Brown et al., 1983; Loehr et al., 1979; Overcash and Pal, 1979). Waste characteristics and waste mass flow allow calculation of the $\mathrm{kg} \mathrm{yr}^{-1}$ produced of each analyzed constituent (such as the organic priority pollutants). Site information (soils, vegetation, ground water, slope, etc.) is collected and estimated rates of assimilation $\left(\mathrm{kg} \mathrm{ha}^{-1} \mathrm{yr}^{-1}\right)$ of each chemical constituent are determined. An environmental nondegradation criterion, which aims to prevent the removal of land from other societal uses, has been used from the early periods of land treatment design (1979-1983) and is largely used as the basis of regulation and guidelines for such systems (Overcash and Pal, 1979). The ratio of generation $(\mathrm{kg}$ $\left.\mathrm{yr}^{-1}\right)$ to assimilation $\left(\mathrm{kg} \mathrm{ha}^{-1} \mathrm{yr}^{-1}\right)$ defines the land area for each waste constituent (Table 3). The constituent requiring the largest area is the LLC. The area required to assimilate the LLC is the area of the land treatment system. Nitrogen is usually the LLC when municipal biosolids and animal wastes are land-applied, while hydraulic loading is the most common LLC for municipal effluent land treatment systems. Industrial land treatment systems may have different LLCs, such as nitrogen, chemical oxygen demand, hydraulic loading, regulated metals, etc., depending on the waste characteristics (Overcash and Nutter, 2001). Designs of land treatment systems are usually developed for each specific waste and soil system, especially when there are permit requirements. However, based on experience with design factors for certain types of wastes (such as municipal biosolids or animal manure systems, which usually are not required to have a permit), designs may be simpli-

Table 3. Example of land application system design (municipal biosolids at $30000 \mathrm{Mg} \mathrm{yr}^{-1} \mathrm{dry}_{\text {biosolids). }}$

\begin{tabular}{|c|c|c|c|c|}
\hline $\begin{array}{l}\text { Biosolids } \\
\text { constituent }\end{array}$ & Concentration & $\begin{array}{l}\text { Generation } \\
\text { rate }\end{array}$ & $\begin{array}{l}\text { Site assimilative } \\
\text { capacity }\end{array}$ & $\begin{array}{c}\text { Land area } \\
\text { needed }\end{array}$ \\
\hline & $\mathrm{mg} \mathrm{kg}^{-1}$ dry solids basis & $\operatorname{kg~yr}^{-1}$ & $\mathbf{k g ~ h a}^{-1} \mathbf{y r}^{-1}$ & ha \\
\hline Nitrogen & 33000 & 990000 & 125 & 8000 \\
\hline Phosphorus & 23000 & 690000 & 100 & 6900 \\
\hline Potassium & 3000 & 90000 & 75 & 1200 \\
\hline Hydraulic & 980000 & 29000000 & 12000000 & 2.5 \\
\hline Copper & 500 & 15000 & 75 & 200 \\
\hline Cadmium & 20 & 600 & 1.9 & 315 \\
\hline Nickel & 40 & 1200 & 21 & 57 \\
\hline Zinc & 700 & 21000 & 140 & 150 \\
\hline $\mathbf{P C B} \dagger$ & 4 & 120 & 2.2 & 55 \\
\hline
\end{tabular}

$\dagger$ Polychlorinated biphenyl. 
fied to incorporate rule-of-thumb factors for specific soil and waste systems.

Assimilation of organic chemicals in a land treatment system is usually accomplished primarily through decomposition. The assimilation capacity of organic chemicals is usually large enough (although it may be low) that the small organic chemical content of most wastes results in much smaller land area requirements than the LLC. Thus, even very slow decomposition rates of some organic chemicals often do not influence the size of the land treatment system. Risks from application of organic chemicals occur when the application rates exceed the assimilative capacity. When this occurs, scientific studies are needed to assure acceptable risks, because it is not only the environmental and health characteristics of an organic chemical that affects the degree of risk, but also the loading of the chemical onto the land treatment system.

\section{DECOMPOSITION}

By far the most important organic chemical pathway that determines limits on the use of land treatment technology is the rate and extent of decomposition of organic constituents present in various wastes (Alexander, 1994; Hamaker, 1972). Klöpffer (1994) has also identified decomposition as the principal pathway defining the satisfactory assimilation of organic chemicals in terrestrial systems. The capability of a land treatment system to achieve complete or partial degradation is the basis of design and the focus of regulation. Decomposition occurs on a continuum from relatively rapid (minutes to hours) to periods of years and can result in either complete contaminant mineralization, formation of partially degraded metabolites that remain in the soil, or incorporation of contaminants into cellular biomass. Both metabolite production and cellular incorporation can contribute to the formation of bound residues (Bollag, 1992; Nieman et al., 1999; Nieman, 2004; Roper and Pfaender, 2001)

Persistent organic chemicals are those that are resistant to decomposition (that is, decompose very slowly). Microbial genetic adaptations may result in microbial communities that can decompose specific organic chemicals that could not do so previously; such changes result in challenges in the interpretation of experimental evidence when studying decomposition (van der Meer, 1997). In addition, the ancillary effect of organic matter applied to soil during land treatment is to stimulate everlarger microbiological populations, which increases the probability that capable microbial communities will evolve to degrade persistent organic constituents.

Very slow decomposition should then be a first characteristic of concern leading to further evaluation of terrestrial effects and risk. What is a very slow decomposition rate that defines a chemical as persistent? And even if persistent, does the presence of the chemical present a risk? Rao and Davidson (USEPA, 1982) define persistent pesticides as those with half-lives of $\geq 100 \mathrm{~d}$, but many organic chemicals degrade at much slower rates. For example, polybrominated diphenyl ethers (PBDEs), used as flame retardants, have been demon- strated by Kevin Jones and others to have expected half-lives in soil of less than six months in the United Kingdom (Hassanin et al., 2004). Also, polyethylene decomposition is widely accepted as very slow (if at all measurable) and would thus pose a concern. However, polyethylene is virtually inert and exhibits no obvious toxicity to microorganisms, animals, plants, or humans. Therefore, the presence of polyethylene in a beneficial reuse system may be aesthetically unpleasing but would pose insignificant risk. In addition, even with low assimilative rates, the very low mass of specific organic chemicals applied in wastes to the soil can mean that a specific organic is not the LLC.

The number of organic chemicals of potential concern in beneficial reuse systems probably equals the number of chemicals used in global commerce (sold in approximately $1 \mathrm{Tg} \mathrm{yr}^{-1}$ or higher, with some exceptions), for they also may be present in wastes produced by industrialized societies. The number of these chemicals is about 90000 , including about 70000 industrial organic chemicals, 10000 agricultural chemicals, and 10000 pharmaceutical species (USEPA, 1986a). These chemicals in commerce are primarily anthropogenic. There is no existing database that addresses the potential of decomposition for all 90000 chemicals, for the resources required to perform such in-depth risk assessments would be enormous (Kester et al., 1998). However, hundreds of published studies have shown that specific organic chemicals have high probabilities of decomposition in a land treatment system.

The importance of decomposition in defining the success of organic chemical assimilation in beneficial reuse systems is demonstrated by the risk assessment studies undertaken with the USEPA Biosolids Rule 12 for dioxin and polychlorinated biphenyls (Federal Register, 2003). These two classes of organic chemicals have been the focus of significant research to understand their behavior in land treatment systems. For both dioxin and polychlorinated biphenyls, the most significant pathway leading to acceptable risk is the decomposition rate (Chaney et al., 1996). Other organic chemicals for which substantial information on terrestrial behavior exists include phthalates, polynuclear aromatic hydrocarbons, halogenated hydrocarbons, and plant-related materials (cellulose, lignin, etc.). Decomposition rates of selected classes of organic chemicals are presented in Table 4.

There is a critical need to identify those organic chemicals that will not significantly decompose in soils. Two models are proposed for defining the subset of anthropogenic organic chemicals with very low decomposition rates in land treatment systems. The first model, based on microbial principles (Bosma et al., 2001), states that the reasons for persistence include:

- adverse environmental factors (e.g., changes from an aerobic to anaerobic environment) (Hurst et al., 1996, 1997);

- lack of enzymes necessary to alter a chemical structure;

- limited uptake into microbial cells, thus limiting intracellular decomposition processes; 
- lack of regulatory proteins that can recognize the organic chemical and induce enzyme synthesis; and/or

- toxicity of the organic chemical affecting microorganisms with degradative potential (Symons and Sims, 1988; Aprill et al., 1990).

The second model consists of an empirical list of persistent organic chemicals developed from the authors' experience and from discussions with soil microbiologists and scientists (M. Alexander, J. Davidson, J. Weber, K. Jones, personal communications, 2003). The list consists of organic chemicals, or groups of chemicals, that appear to have low or no decomposition rates in land treatment systems, including:

- one- and two-carbon halogenated species with vapor pressures that favor loss through volatilization before significant decomposition can occur (even though decomposition may be possible);

- families of isomers or related chemicals that are degradable at lower molecular weights and higher solubilities, but as the solubility decreases and the molecular size increases, become less and then nondegradable [such as polynuclear aromatics with more than about six rings (USEPA, 1988), polychlorinated biphenyls with more than about five chlorines, and dioxins with more than about four chlorines]. Although solubility is used as the defining characteristic in this classification, other microbial mechanisms or effects are likely to control decomposition. Solubility is used as a surrogate characteristic because other factors are difficult to measure or define;

- polymers designed to resist decomposition, such as nylon, polyethylene, and other plastic materials; and

- some quaternary carbon structures (Alexander, 1994) and some ether linkages (Alexander, 1973).
Table 4. Range of decomposition rates of organic chemicals in soil systems (Overcash and Pal, 1979).

\begin{tabular}{lc}
\hline Chemical & Half-life \\
\hline & $d$ \\
Hydroquinone & 0.5 \\
Pyrocatechin & 0.5 \\
Testosterone & $0.5-8$ \\
17ß-Estradiol & $1-10$ \\
Phenol & 1.3 \\
2,4-Methylaniline & 1.5 \\
17ß-Ethynyl estradiol & $3-10$ \\
Acetic acid & $5-8$ \\
Cellulose & 35 \\
Octylphenol & 35 \\
$n$-Nitrosodiethlyamine & 40 \\
Nonylphenol & $\mathbf{8 0}$ \\
Di-n-butyl phthalate ester & $\mathbf{8 0 - 1 8 0}$ \\
Anthracene & $\mathbf{1 1 0 - 1 8 0}$ \\
Benzo(a)pyrene & $\mathbf{6 0 - 4 2 0}$ \\
Nonionic surfactant & $\mathbf{3 0 0 - 6 0 0}$ \\
Aminoanthroquinone dye & $\mathbf{1 0 0 - 2 0 0 0}$ \\
Polydimethylsilicone & $\mathbf{9 0 0 - 1 4 0 0}$ \\
\hline
\end{tabular}

The properties of new and/or unstudied chemicals can be compared with the properties of these known persistent chemicals to evaluate potential persistence in beneficial reuse systems.

The waste matrix (i.e., biosolids, animal wastes, or effluent) may also affect organic chemical decomposition, although there is not a significant amount of research that directly addresses the principles or mechanisms that may cause the effects. However, there are published studies where specific organic chemicals were applied to soils directly and also in conjunction with biosolids or animal manures. The ratios of rates of decomposition between pure chemical and chemical in a waste matrix are compared in Table 5. Rates of decomposition of pure chemicals were greater than rates of decomposition of the same chemical in a waste matrix

Table 5. Evaluation of waste matrix effect on decomposition of specific organic compounds on soil.

\begin{tabular}{|c|c|c|c|}
\hline \multirow[b]{2}{*}{ Chemical } & \multirow[b]{2}{*}{ Soil } & \multicolumn{2}{|c|}{ Decomposition rate ratio: wastes and soil to soil } \\
\hline & & Greater than 1 & Less than 1 \\
\hline 3,3-Dichlorobenzidine & Rubicon sand & & $0.53-0.88$ \\
\hline \multirow{3}{*}{ 2,4-Dichlorophenoxyacetic acid } & Glendale & 1-1.3 & $0.5-1$ \\
\hline & Harvey & $0.25-0.75$ & \\
\hline & & & \\
\hline \multirow[t]{3}{*}{ 2,4,5-Trichlophenoxyacetic acid } & Glendale & $0.81-1.24$ & $0.75-1$ \\
\hline & Harvey & & $0.36-0.63$ \\
\hline & Lea & & \\
\hline cis-Parmethrin & Metapeake silt loam & $1.67-2.33$ & \\
\hline \multirow{3}{*}{ Arochlor } & Glendale & 1.09-1.74 & \\
\hline & Lea & $1.3-2.5$ & \\
\hline & Harvey & $1.4-2.5$ & \\
\hline \multirow[t]{3}{*}{ Di-2-ethylhexyl phthalate } & Glendale & $0.75-1.1$ & $0.83-1.3$ \\
\hline & Lea & & $0.8-1.3$ \\
\hline & Harvey & & \\
\hline Atrazine & Metapeake silt loam & $0.55-1.4$ & \\
\hline Chloropropham & Metapeake silt loam & & $0.8-0.93$ \\
\hline 2,4-Dichlorophenoxyacetic acid & Metapeake silt loam & & $0.64-1.08$ \\
\hline Dalapon & Metapeake silt loam & & $0.8-1$ \\
\hline Dinoseb & Metapeake silt loam & 1-1.7 & \\
\hline Diuron & Metapeake silt loam & $0.5-1.3$ & \\
\hline EPTC & Metapeake silt loam & & 0.9-1 \\
\hline Linuron & Metapeake silt loam & & $0.7-1$ \\
\hline PCMC & Metapeake silt loam & $0.9-1.25$ & \\
\hline Permethrin & Metapeake silt loam & & $0.4-0.6$ \\
\hline Propachlor & Metapeake silt loam & $0.9-1.7$ & \\
\hline Trifuralin & Metapeake silt loam & 0.8-1.15 & \\
\hline Arochlor & Metapeake silt loam & & $0.8-0.9$ \\
\hline Chloropyrifos & Toronto & & $0.8-0.9$ \\
\hline Chloropyrifos & Raub & $0.9-1.2$ & \\
\hline
\end{tabular}


in about half the studies but were lower in the remaining studies. Sorption of the chemical may have lowered the decomposition rates when wastes were present, while for other chemicals the addition of wastes may have stimulated microbial activity. In both cases, the range of deviation was about \pm 10 to $30 \%$.

As decomposition occurs, nondegradable (persistent) intermediates can form. An assessment of whether these intermediates are of greater environmental risk should be performed in cases of potentially high risk. For example, DDT (dichlorodiphenyltrichloroethane) decomposes to DDE (dichlorodiphenyldichloroethylene), which can persist in soil environments for decades and for extended periods in laboratory studies with pure and mixed cultures (Huang et al., 2001; Thiele et al., 1999; Megharaj et al., 1998; Strompl and Thiele, 1997), despite the potential for degradability observed in some systems (Morrison et al., 2000; Hay and Focht, 1998; Quensen et al., 2001; Sharma et al., 1987). Breakdown products for many organic chemicals include nontoxic organic metabolites, carbon dioxide, and water and incorporation into soil microbial cells and humus. Unlike DDT, which has a low rate of decomposition, and the even more persistent DDE, parent organic compounds with medium to high rates of decomposition generally produce breakdown products that are also likely to decompose in aerobic environments. For nonagricultural chemicals, few examples of persistent metabolites (not including humus) are known.

\section{BOUND RESIDUE FORMATION}

Many compounds including hydrophobic compounds have been observed to form bound residues in soil systems through multiple mechanisms, and research results show that they should be stable in land treatment systems. Bound residues formed by pesticides have been recently reviewed by Gevao et al. (2000). Phenolic and analinic compounds have been shown to form enzymatically catalyzed bonds with humic materials (Bollag, 1992). Bound residues are observed in treatability studies of hydrophobic compound such as PAHs (Sims and Abbott, 1993; Guthrie and Pfaender, 1998; Richnow et al., 1998; Nieman et al., 1999; Roper and Pfaender, 2001), PCBs (Kubatova et al., 1998; Burauel and Fuhr, 2000; Schnabel and White, 2001; Green et al., 1999), and polybrominated diphenyl ethers (Hassanin et al., 2004). Bound residue formation has also been shown to be a significant fate of estrogenic compounds in soil systems (Hanselman et al., 2003).

Potential bonding mechanisms of contaminants with soils are known and include ionic bonding (cation exchange), hydrogen bonding, charge transfer (electron donor-acceptor), covalent binding (nucleophilic addition and oxidative coupling reactions), ligand exchange, dipole-dipole and Van Der Waals forces, and hydrophobic adsorption and partitioning (Senesi and Miano, 1995), but the extent of the involvement of these mechanisms in bound residue formation is not known. Other proposed mechanisms for bound residue formation also include the incorporation of produced $\mathrm{CO}_{2}$ (Kastner et al., 1999) into the soil matrix and the incorporation of contaminant metabolites into cellular biomass (Annweiler et al., 2001; Nieman, 2004).

Because increased formation of bound residues is often observed with biological activity, current hypotheses about their formation primarily involve the reaction of partially degraded metabolites with reactive soil components such as humic materials. Richnow et al. (1997) have proposed such a mechanism for PAH bound residue formation in which oxidized PAH metabolites react with humic materials and form covalent ether or ester bonds. Green et al. (1999) also suggest this as a possible mechanism of 4-fluorobiphenyl bound residue formation. Annweiler et al. (2001) points out that bound residues formed through defined metabolite reactions with humic materials may represent only a small fraction of the observed residues and that many residues may be anabolic products of bacterial degradation. This potential endpoint is supported by the findings of Richnow et al. (2000) and Nieman (2004).

Biodegradation and biological bound residue formation have been shown to reduce contaminant concentrations, mobility, toxicity, and mutagenicity in soil systems (Wang et al., 1990; Loehr and Webster, 1997; Nieman, 2004). Richnow et al. (1999) report that bound residues of anthracene were relatively resistant to microbial degradation. Eschenbach et al. (1998) exposed residues from naphthalene, anthracene, pyrene, and benzo $(a)$ pyrene to various environmental stresses including bacterial and fungal degradation, freeze-thaw cycles, and EDTA complexation. Biological treatment resulted in some mineralization ranging from 4 to $5 \%$ for $\operatorname{benzo}(a)$ pyrene to 14 to $18 \%$ for pyrene residues and was comparable with natural rates of humus decomposition. Freezethaw cycles were not found to increase extractability of the bound residues, but treatment with EDTA did increase residue mobility, presumably through solubilization of residue-associated organic material that did not exceed $20 \%$ of the initial bound residue content. Eschenbach et al. (2001) also report similar results for physical and chemical treatments of TNT residues. They also conducted a simulated acid rain exposure by repeated extraction with aqueous solutions of nitric and sulfuric acid and found that less than $15 \%$ of the bound residues were extractable. These findings support the conclusion that biologically produced bound residues are relatively immobile, degrade at rates similar to natural soil materials, and should present a significantly reduced risk to the environment as opposed to parent contaminants.

\section{LEACHING AND RUNOFF}

Additional pathways that must be considered in beneficial reuse practices are the downward migration of organic chemicals with percolating water through soils and surface water runoff to adjacent waters. Generally, the most important chemical characteristic for understanding soil-water transport of an organic chemical is the charge (cationic, anionic, or nonionic) of the chemical. However, for organic species, sorptive processes associated with soil and waste organic matter strongly 
influence migration, for sorption includes both charge and noncharge binding processes.

Organic chemical migration in beneficial reuse systems does not appear to be significant (Kaufman, 1983) or widely documented, although only limited information is available (Howie, 1991). Recent reports of estrogenic compounds in runoff from land-applied manure need to be studied further because of the use of ambiguous quantification methods (Hanselman et al., 2003). The loading rates in land treatment systems are typically low (Table 2), often much lower than the application rates of pesticides and agricultural chemicals. No comprehensive summary of the organic chemical migration from land treatment systems has been developed. It should also be noted that organic chemical migration has been observed from landfills, which have much higher loading rates (Table 2) than from beneficial reuse land treatment systems. The principal difference in organic chemical migration from landfills is related to the sustained hydraulic head (or driving force) that carries chemicals downward. Also, landfills do not operate with the aerobic decomposition pathways found in land treatment. The ability to overcome land treatment soil assimilation capacity under landfill conditions is also evidenced by documented migration of regulated metals.

A first source of information for the potential for migration of organic chemicals in beneficial reuse systems is from studies of hazardous waste land treatment systems (HWLT). Soil core and well data from about 10 HWLT sites revealed no organic chemical migration below the zone of incorporation (Brown, personal communication, 2003). The waste loading rates at HWLT sites are typically greater than those of biosolids beneficial reuse systems. Of the more than 1200 U.S. Superfund sites, none are former land treatment systems, suggesting that migration of organic chemicals with soil water is not extensive. For one Superfund site using landfarming for treatment of wood preservative-contaminated soil, a comprehensive study of the fate of priority pollutant PAHs and pentachlorophenol (PCP) in soil over a two-year period showed no downward migration of target organic chemicals (USEPA, 1996). A review of the fate of organic chemicals in landfarms containing petroleum-contaminated soils also indicated minimal downward migration or runoff (Sims and Sims, 1999).

In an in-depth study of three refinery HWLT sites, Streebin et al. (1984) examined soil cores and vadose zone soil water for the presence of organic chemicals. No significant detection of organic priority pollutants in the soil water was found for two of these sites. Low levels, mostly of nitrophenols, were found at a third site, but the soils from corresponding depths evidenced no organic priority pollutants above detection limits (about $1 \mathrm{ng} \mathrm{L}^{-1}$ ). At two major municipal biosolids systems (in Barceloneta, Puerto Rico, with $10 \mathrm{yr}$ of monitoring, and Chicago), monitoring wells were used to detect organic priority pollutant migration. In both cases, the analytical observations were random, nonrecurring detections of the organic priority pollutants, implying that migration was not substantial nor verifiable. Thus, unlike in agricultural chemical systems where there are high proba- bilities of both the presence and recurring detection (sometimes approaching $60 \%$ of wells) of organic chemicals, these land treatment systems showed no significant, measurable organic chemical migration of the common priority pollutants. Discussion with two large land treatment firms (B. O'Dette, Synagro, and G. Springer, CES, personal communications, 2003) revealed that analyses of specific organic chemicals are rarely conducted because they are not part of regulatory requirements.

A second source of information on the potential of migration of organic chemicals in beneficial reuse systems can be obtained from studies of the terrestrial field use of agricultural chemicals in plant-soil systems. There are small molecular organic anions, such as sulfonylurea, that, if applied at levels above the small finite anion exchange capacity of most soils or at loading rates higher than decomposition rates, can be expected to have a potential for migration. However, agricultural chemicals are applied in carriers that do not contain the organic materials with significant organic sorption capacity that are associated with many waste materials.

Information for agricultural chemicals provides an evolving phenomenological description of soil water migration in full scale systems (J. Troiano, personal communication, 2001; S. Rao, personal communication, 2003). This migration pathway is represented in Fig. 1, in which a continuum, convective transport path coexists with the more amorphous, poorly understood "facilitated" pathways. The "facilitated" pathways are a combination of more rapid flow mechanisms such as can occur in microchannel flow, macro-soil structure interfaces, anthropogenic direct flow (well casings, runoff collection in bore holes, abandoned borings), natural occurrence at depth, and human error in sampling and analysis. These mechanisms appear to depend less on the usual chemical properties and occur in land treatment systems as well as in agricultural processes. However, the results for beneficial reuse systems appear to be different (even though loadings are more or less similar) from agricultural chemicals and may help us understand which facilitated mechanisms are more significant.

A third source of information is related to the high level of organic chemicals in nature that have been present through geologic time. Organic levels in a typical forest or productive agricultural soil range from 2 to $8 \%$ of organic matter, constituting 20000 to $80000 \mathrm{mg}$ $\mathrm{kg}^{-1}$ of a mixture of organic chemicals. Waksman (1938), Schnitzer and Khan (1972), Kononova et al. (1966), and others have described the chemical composition of this organic, or humic, zone. In the humic zone, typical concentrations of acidic, basic, and nonionic organic chemicals in soil include $80 \mathrm{mg} \mathrm{L}^{-1}$ benzoic acid, $23 \mathrm{mg} \mathrm{L}^{-1}$ trithiobenzaldehyde, $6 \mathrm{mg} \mathrm{L}^{-1}$ cyanuric acid, and $65 \mathrm{mg}$ $\mathrm{L}^{-1}$ 3,4,5-hydroxyacetaphenone. These concentrations have probably existed for millions of years as a potential source for migration to ground water from areas similar to land treatment systems. However, concentrations of these naturally organic chemicals in natural ground water are generally nondetectable. This is a long-term "experiment," involving soil pores and other migration channels that are also found in beneficial reuse systems; 


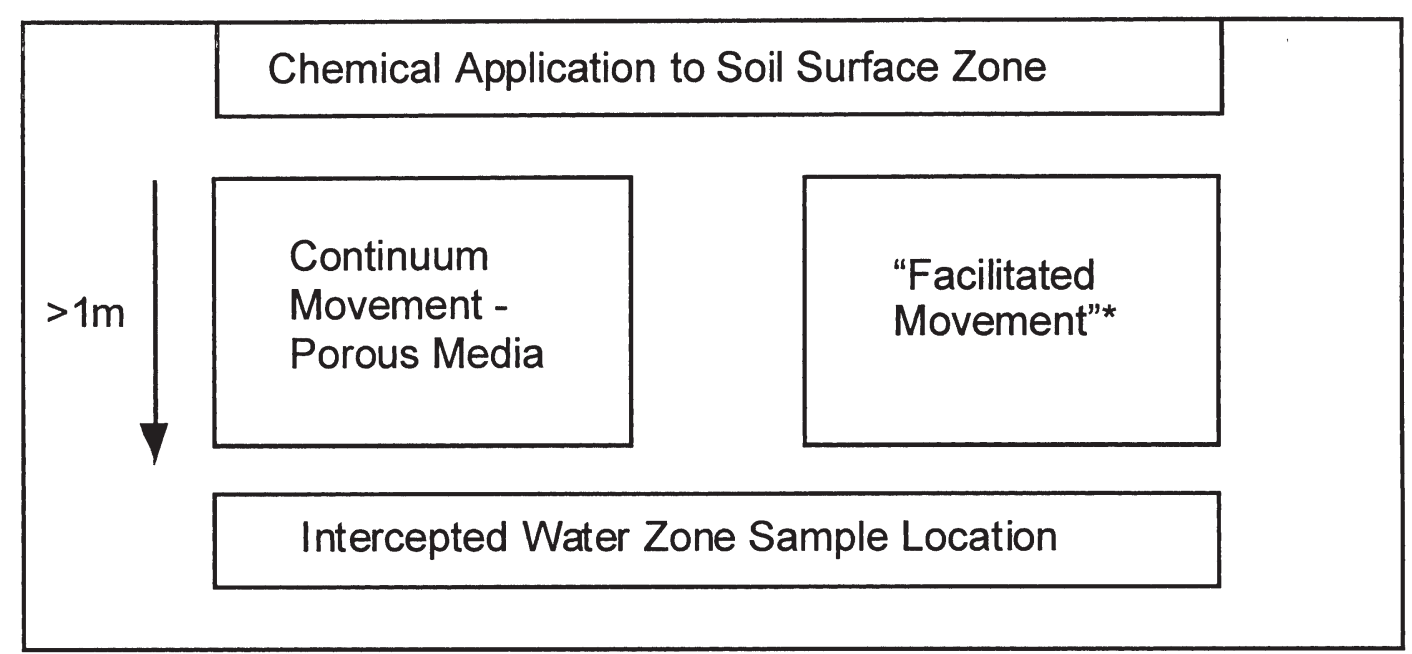

Aerobic, agricultural system with design for land treatment

\section{*Small biota channels \\ Macro channels \\ Macro soil structure interfaces \\ Anthropogenic direct flow \\ Existence of natural chemical sources \\ Human sampling and analytical contamination}

Fig. 1. Conceptual model developed in parallel by several research groups to provide overview of migration of organic chemicals in specific terrestrial systems.

thus we can conclude that significant organic migration under beneficial reuse system conditions is unlikely.

Surface runoff of particulate and soluble materials from land to surface waters is a direct consequence of rainfall and soil conditions and occurs from virtually all land uses. Runoff is managed through the use of best management practices (BMPs) (e.g., riparian setback distances, use of buffer strips, and other management practices for activities on land). Best management practices do not result in zero discharge of contaminants and can contribute to nonpoint source pollution of aquatic systems. One of the most effective BMPs for biosolids beneficial reuse is incorporation of the waste materials into the soil rather than surface application. While neither system ensures no runoff of materials, the soilincorporated application method results in orders of magnitude lower runoff (Ross et al., 1978).

There have been some studies of specific organic chemicals in runoff from land treatment systems. In one study, a refinery land treatment system was studied with a rainfall simulator (USEPA, 1986b). In a second study, rain events were monitored at a site where poultry wastes were freshly applied to the surface of a fescue grass (Finlay-Moore et al., 2000). In a third study, surface runoff as a result of surface irrigation of individual agricultural fields in coastal southern California was analyzed for organic compounds including pesticides, personal care products, and pharmaceutically active compounds de- rived from treated wastewater used for irrigation (Pedersen et al., 2002). In a fourth study, water quality constituents from rainfall and storms producing surface water runoff from crop-based agriculture that was not used for land application of waste provided information on herbicides and insecticides as well as defoliants, desiccants, growth regulators, and nutrients applied to crops annually (Eddleman et al., 1999). A fifth study monitored a 25-yr, 24-h rainfall runoff event at a refinery land treatment system and found no organic priority pollutants (lower detection limit [LDL] $0.1 \mathrm{ng} \mathrm{L}^{-1}$ ) in the runoff (Streebin et al., 1984).

An approach to understanding the data from these studies that did find detectable contaminant concentrations in runoff involves the examination of waste runoff behavior in comparison with runoff quality from control areas not receiving waste application. The ratio of waste runoff concentrations from the application area to a control area (which did not receive waste application) is compared with the ratio of soil concentrations from the application area to that of the control area (Fig. 2). In general, the ratios for runoff concentrations are less than the ratios for soil concentrations, indicating that the soil acts to reduce runoff. Concentrations of specific organic chemicals in runoff are low, while aggregate organics (total organic carbon [TOC] and total chromatographicable organics [TCO]) are greater. Total nitrogen $(\mathrm{TN})$, copper $(\mathrm{Cu})$, and chromium $(\mathrm{Cr})$ had greater 


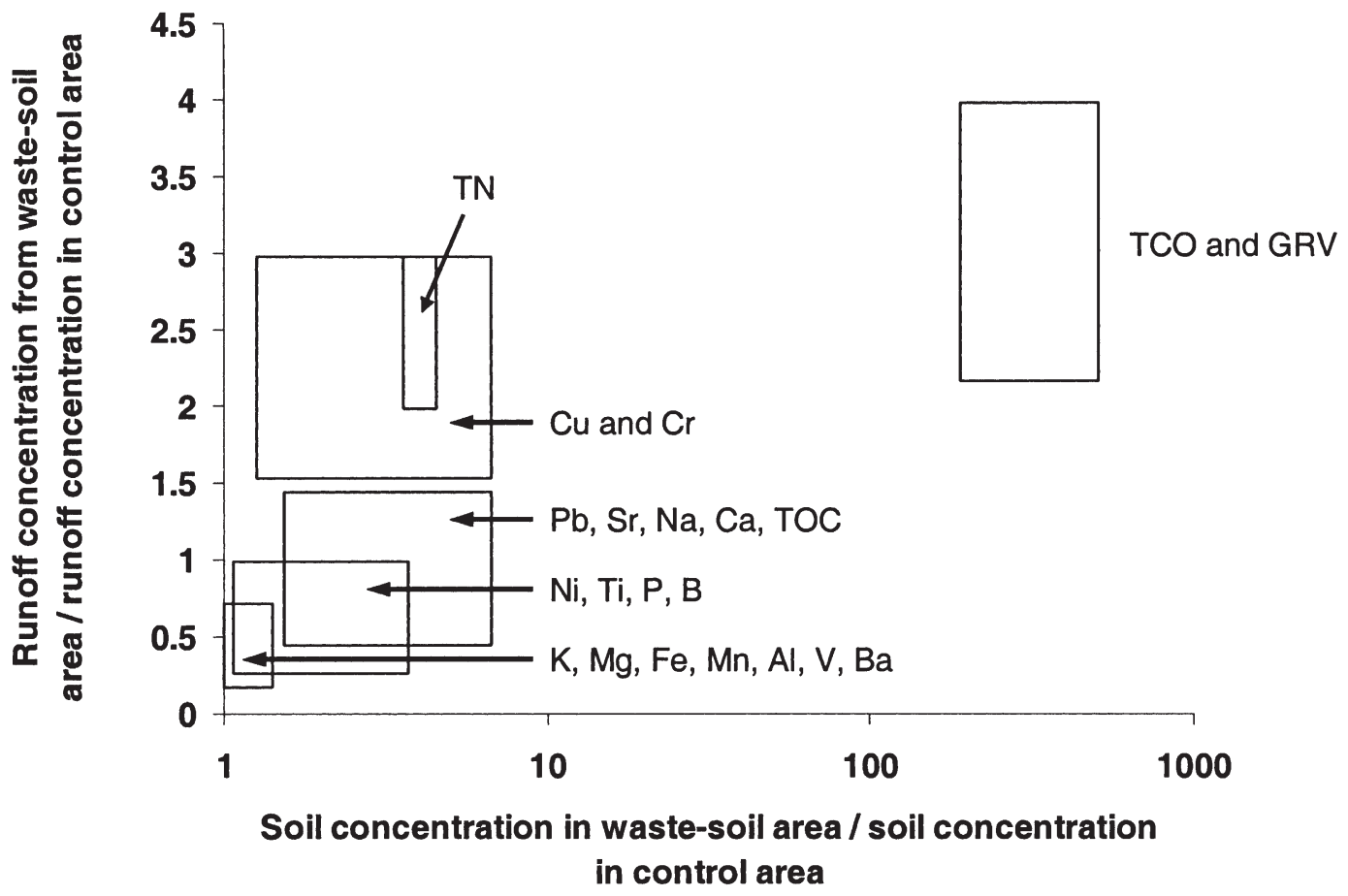

Fig. 2. Relation of waste applied area rainfall runoff concentrations to control areas. GRV, gravimetric organic analysis; TN, total nitrogen; TCO, total chromatographicable organics; TOC, total organic carbon.

ratios of runoff concentrations to soil concentrations than other waste constituents, while many of the metals exhibited lower ratios. The specific polynuclear aromatic compounds (PNAs) in runoff were on the order of 0.04 to $0.08 \%$ of the PNAs in the waste soil complex (USEPA, 1986b).

\section{CROP UPTAKE}

Crop uptake of organic chemicals is a competing pathway to decomposition, bound residue formation, soil water migration, and surface runoff. Transfer of organic chemical compounds into plant roots and subsequent translocation within the plant has been widely studied for agricultural chemicals, but much less so for nonagricultural organic commercial chemicals. The potential for agricultural and waste-based nonagricultural chemicals to be taken up into plants is affected by the presence of other organic materials such as biosolids.

Uptake studies for nonagricultural organic chemicals have been undertaken for a significant number of chemicals and plant species (Topp et al., 1986; McFarlane et al., 1987; Kirchmann and Tengsved, 1991; Schroll and Scheunert, 1992; Nellessen and Fletcher, 1993; Schroll et al., 1994; O'Connor, 1996; Dietz and Schnoor, 2001; Bock et al., 2002; Li et al., 2002; White et al., 2003), but many of these studies do not involve biosolids. Many of these studies used ${ }^{14} \mathrm{C}$ (carbon)-labeled chemicals, which can overestimate plant uptake, because the chemicals measured in uptake may be smaller molecular weight breakdown products carrying the ${ }^{14} \mathrm{C}$ label.

Li (1994) compared plant uptake of 2,2',4,4'-tetrachlorobiphenyl (TCB) and benzo $(a)$ pyrene at moderately low soil concentrations $\left(1-20 \mathrm{mg} \mathrm{L}^{-1}\right)$. The ratio of ${ }^{14} \mathrm{C}$ label to parent compound measured by high performance liquid chromatography (HPLC) was 8 to 38 for TCB and 3 to 7 for benzo( $a$ )pyrene. Wheeler (2003) evaluated potential plant uptake of nonylphenol ethoxylate (NPE) and nonylphenol (NP) surfactants (NP, NPE $\mathrm{NPE}_{9}$ ) using both radiolabeled and nonradiolabeled parent compounds. While the majority of ${ }^{14} \mathrm{C}$ was found associated with roots $(>81 \%)$, only a small fraction $(<1 \%)$ was found in the foliar tissue. No parent compounds were detected in foliar tissue, implying that the ${ }^{14} \mathrm{C}$ was associated with transformation products. Results from these studies indicate that direct uptake of parent compounds and translocation in plants for nonagricultural organics found in wastes are not a major pathway for most plant species, although apparent exceptions have been found (White et al., 2003). This is consistent with the conclusions by Chaney et al. (1996) and O'Connor (1996) that direct foliar deposition during waste application was more likely to be the crop-related pathway of significance, rather than uptake through plant roots.

An additional mechanism that affects plant uptake of specific organic chemicals is the internal plant processes that react with and transform organic chemicals. While these processes are well known for agricultural chemicals, few studies have been conducted to determine the fate of nonagricultural chemicals in plants after uptake (Dressel, 1976). Internal decomposition and chemical transformation within the plant contribute to difficulties associated with analyses to determine risk of human or animal ingestion of plant materials containing organic chemicals.

Models of uptake of organic chemicals by plants have been evaluated and presented by Fryer and Collins (2003). Three dynamic, three regression-based, and three steady- 
state equilibrium models were evaluated that considered plant contamination via both soil and aerial exposure pathways. Model performance was evaluated using experimental results from nine different studies. Equilibrium and steady-state models performed best under conditions of chronic exposure durations, where stable conditions are more likely to exist. Hung and Mackay (1997) developed a fugacity-based model for predicting the uptake of organic chemicals from soil into leaf, stem, and root compartments in plants. The model is intended for use in assessment of exposure to, and risk from, contaminants for agricultural plants. These models have been used on a limited basis, but with minimal fieldbased behavior and performance validation. Specific chemical-plant processes including uptake, translocation, accumulation, and biotransformation were summarized in a comprehensive database by Nellessen and Fletcher (1993). Results demonstrate that there is an imbalance of attention given to agrochemicals (90\% of data) versus industrial and municipal waste compounds over the 80 -yr period covered by the database. Paterson et al. (1990) identified correlations between plant uptake and octanol-water and octanol-air partition coefficients and emerging useful mathematical models. Based on the small amount of integrated mathematically modeling and experimental results, a need exists to develop more information on nonagrochemicals with regard to plant uptake, and to connect models with full-scale performance and monitoring at more land application sites to generate robust and accurate model predictions for assessment of crop uptake for sustainable land application systems.

\section{OBSERVATIONS}

The assimilation of specific organics under land treatment conditions is a complex area of research for which we are making steady progress toward quantitative understanding. This review of the state-of-the-art results in the following observations:

- Use of resources to research issues that are not significant to improving land application, but which are issues in other terrestrial or aquatic environments, should be avoided by recognizing quantitatively the major differences in these environments.

- Decomposition is the major pathway for assimilation of specific organics and is a priority research area to meet beneficial reuse goals for land application systems. This priority has been verified by the two most studied specific organic chemicals in beneficial reuse systems (i.e., dioxins and PCBs).

- Chemicals in commerce represent about 90000 specific organic chemicals that may occur in wastes. Excluding plastics and polymers, there are relatively few organic classes that are persistent in terrestrial land application systems. Therefore, it is reasonable to assume a specific organic (current and new) chemical will decompose in a land treatment system. However, for beneficial reuse, the rate of decomposition must be estimated or measured as one of the most critical factors in land treatment system design and in evaluating risk.

- Decomposition is enhanced by incorporation of wastes into soil, which also has a positive effect on risk reduction for direct exposure of vegetation to waste, ingestion by humans and animals, and runoff transport of specific organic chemicals.

- Those chemical classes believed to be persistent should to be identified using empirical and mechanistic approaches.

- The fate of nonagricultural specific organic chemicals in biosolids, effluents, or wastes is influenced by the waste organic matrix, which affects soil water transport, plant uptake, and runoff behavior and may be different than the fate of agricultural chemicals applied directly to agronomic soils.

- Biologically produced bound residues are relatively immobile, degrade at rates similar to natural soil materials, and should significantly reduce risks to the environment compared with the risks associated with parent contaminants. A major mechanism for biologically bound residue formation appears to be incorporation of contaminant carbon into microbial cellular biomass.

- From the information available, movement of landapplied organic chemicals in wastes or organic chemicals residing naturally in the soil (whether by uniform flow or "facilitated" mechanisms) over significant soil distance does not appear to occur at measurable or adverse rates. This observation is based on the priority pollutant organic chemical classes studied.

- Plant uptake of specific organics from land-applied wastes appears to occur at very low rates and to a low extent. These rates are not well documented by direct parent analysis. The dependence of the experimental findings on ${ }^{14} \mathrm{C}$ studies within aqueous solutions appears to substantially overestimate such uptake.

- In assessing nonpoint-source transport of specific organic chemicals from land application systems, it is important to have control areas for direct event comparisons, as movement of material is common in all terrestrial systems. The limited information on specific organic chemicals suggests low amounts in rainfall runoff from land application systems, and $503 \mathrm{~b}$ risk pathways do not indicate that this is a major limitation (USEPA, 1995). Society continues to rely on best management practices (BMPs) and enforcement to provide acceptable quality from rainfall runoff from all land areas.

- The limited technology choices for biosolids and other wastes implies that acceptance of some risks and the occurrence of some benefits will continue to characterize land application practices. Land treatment contributes directly to emerging goals of sustainability (Sims and Sims, 2003).

\section{RECOMMENDATIONS}

First, new chemicals of environmental interest present at relatively high concentrations (when compared with 
priority pollutants) in wastes (such as animal manures, biosolids, etc.) should be monitored in the areas under land application systems to document behavior. Second, migration of higher-concentration chemicals in landapplied wastes via runoff and as soil water transport should be studied in the field at more sites and under dynamic weather and climate conditions. There has been relatively little monitoring of organic chemicals in fullscale land application systems. Such studies would provide information for better quantification of the level of risk.

\section{CONCLUSIONS}

Land treatment of organic wastes is a technology that has economical advantages for application to international areas where there is a desire to retain and enhance agricultural systems for sustainable production, while conserving water through waste reuse and protecting ground water and surface water natural resources. The potential for application of modern land treatment technology for support for global waste reuse and environmental sustainability is large. Within this context, research is needed to develop information to address the design of land treatment systems for wastes containing new anthropogenic chemicals including pharmaceuticals, antibiotics, surfactants, cosmetics, and estrogenic compounds.

\section{ACKNOWLEDGMENTS}

Support for the preparation of this manuscript was provided by a grant from the Huntsman Environmental Research Center (HERC) at Utah State University (Dr. Maurice Thomas, Director), and through support provided by the Department of Biological \& Irrigation Engineering and the Utah Water Research Laboratory at Utah State University.

\section{REFERENCES}

Addison, J.B. 1997. Organic chemicals in sediments and runoff-waters from feedlots. Toxicol. Environ. Chem. 63:149-162.

Adriano, D.C., J.-M. Bollag, W.T. Frankenberger, and R.C. Sims. 1999. Bioremediation of contaminated soils. Agron. Monogr. 37. ASA, Madison, WI.

Alexander, M. 1973. Nonbiodegradable and other recalcitrant molecules. Biotechnol. Bioeng. 15:611-647.

Alexander, M. 1994. Biodegradation and bioremediation. Academic Press, San Diego, CA.

Amornprasertsook, K., and C. Polprasert. 1996. Toxicity and removal of phenol by a land treatment system. Chemosphere 17:783-788.

Andersen, H., H. Ruedisiergrist, B. Thalling-Sorensen, and T. Ternes. 2003. Fate of estrogens in a municipal sewage treatment plant. Environ. Sci. Technol. 37:4021-4026.

Annweiler, E., H.H. Richnow, and W. Michaelis. 2001. The significance of bound residues in the bioremediation process of PAH contaminated sites. p. 253-269. In R. Stegmann (ed.) Treatment of contaminated soil: Fundamentals, analysis, applications. Springer, Berlin.

Aprill, W., R.C. Sims, J.L. Sims, and J.E. Matthews. 1990. Assessing detoxification and degradation of wood preserving and petroleum wastes in contaminated soil. Waste Manage. Res. 8:45-65.

Bechmann, W., and K. Grunewald. 1995. Organic pollutants in soils and substrates of the sewage farm area south of Berlin. (In German, with English abstract.) Z. Pflanzenernaehr. Bodenkd. 158:543-548.

Bock, C., M. Kolb, M. Bokern, H. Harms, M. Mackova, L. Chroma, T. Macek, J. Hughes, C. Just, and J. Schnoor. 2002. Advances in phytoremediation: Phytotransformation. NATO Sci. Ser. 4 15:115-140.
Bollag, J.-M. 1992. Decontaminating soil with enzymes. Environ. Sci. Technol. 26:1876-1881.

Bosma, T., H. Harms, and A. Zehnder. 2001. Biodegradation of xenobiotics in environment and technosphere. p. 164-202. In O. Hutzinger (ed.) Handbook of environmental chemistry. Vol. 2. Part K. Springer Verlag, New York.

Brown, K., G. Evans, and B. Frentrup. 1983. Hazardous waste land treatment. Butterworth Publ., Woburn, MA.

Burauel, P., and F. Fuhr. 2000. Formation and long-term fate of non-extractable residues in outdoor lysimeter studies. Environ. Pollut. 108:45-52.

Center for Environmental Analysis. 2002. Exposure analysis for dioxins, dibenzofurans, and coplanar polychlorinated biphenyls in sewage sludge. Technical background document, draft. Center for Environ. Analysis, Research Triangle Park, NC.

Chaney, R., J. Ryan, and G. O'Connor. 1996. Organic contaminants in municipal biosolids: Risk assessment, quantitative pathways analysis, and current research priorities. Sci. Total Environ. 185: 187-216.

Christen, K. 2003. NDMA: One of the latest emerging contaminants. Water Environ. Technol. 15:21-24.

Couillard, D., and Y. Grenier. 1990. Evaluation of the environmental risks associated with the use as fertilizer of municipal sewage sludge containing toxic organic contaminants. (In French, with English abstract.) Water Pollut. Res. J. Can. 25:109-130.

Dietrich, A.M., S.A. Chesnutt, L.A. Stone, and D.L. Gallagher. 1993. Determination of organic pollutants in land applied municipal wastewater sludges by toxicity characteristic leaching procedure (TCLP) and extraction procedure toxicity test (EP). Water Environ. Res. 65:612-619.

Dietz, A.C., and J.L. Schnoor. 2001. Advances in phytoremediation. Environ. Health Perspect. Suppl. 109:163-168.

Dressel, J. 1976. Relationship between nitrate, nitrite and nitrosamines in plants and soils. Plant Foods Hum. Nutr. 25:381-390.

Eddleman, B.R., C. Livingston, and W.B. Prince. 1999. Analysis of runoff water from croplands in the south Texas coastal plains. p. 12951298. In Proc. of the Beltwide Cotton Conf., Orlando, FL. 3-7 Jan. 1999. Vol. 2. Natl. Cotton Council, Memphis, TN.

Eschenbach, A., H. Mesher, R. Weinberg, and B. Mahro. 2001. Humification of PAH and TNT during bioremediation-Evaluation of long term risk and sustainability. p. 271-291. In R. Stegmann (ed.) Treatment of contaminated soil; fundamentals, analysis, applications. Springer, Berlin.

Eschenbach, A., R. Weinberg, and B. Mahro. 1998. Fate and stability of nonextractable residues of $\left[{ }^{14} \mathrm{C}\right] \mathrm{PAH}$ in contaminated soils under environmental stress conditions. Environ. Sci. Technol. 32:2585-2590.

European Union. 2000. Working document on sludge. 3rd draft. EU, Brussels.

Federal Register. 2003. Standards for the use or disposal of sewage sludge. Fed. Regist. 68:61084-61096.

Finlay-Moore, O., P.G. Hartel, and M.L. Cabrera. 2000. 17 $\beta$-Estradiol and testosterone in soil and runoff from grasslands amended with broiler litter. J. Environ. Qual. 29:1604-1611.

Fryer, M.E., and C.D. Collins. 2003. Model intercomparison for the uptake of organic chemicals by plants. Environ. Sci. Technol. 37:1617-1624.

Gevao, B., K.T. Semple, and K.C. Jones. 2000. Bound pesticide residues in soils: A review. Environ. Pollut. 108:3-14.

Golet, E.M., I. Xifra, H. Seigrist, A.C. Alder, and W. Giger. 2003. Environmental exposure assessment of fluoroquinolone antibacterial agents from sewage to soil. Environ. Sci. Technol. 37:3243-3249.

Green, N.A., A.A. Meharg, C. Till, J. Troke, and J.K. Nicholson. 1999. Degradation of 4-fluorobiphenyl in soil investigated by $19 \mathrm{~F}$ NMR spectroscopy and $14 \mathrm{C}$ radiolabelling analysis. Chemosphere 38:1085-1101.

Guthrie, E.A., and F.K. Pfaender. 1998. Reduced pyrene bioavailability in microbially active soils. Environ. Sci. Technol. 32:501-508.

Hale, R., M. LaGuardia, E. Harvey, M. Gaylor, T. Mainor, and W. Duff. 2003. Persistent pollutants in land-applied sludges. Nature (London) 412:140-141.

Hamaker, J. 1972. Decomposition: Quantitative aspects. p. 253-340. In C. Goring and J. Hamaker (ed.) Organic chemicals in the soil environment. Vol. 1. Marcel Dekker, New York.

Hanselman, T.A., D.A. Graetz, and A.C. Wilkie. 2003. Manure-borne 
estrogens as potential environmental contaminants: A review. Environ. Sci. Technol. 37:5471-5478.

Harmsen, J. 2004. Land treatment of PAH and mineral oil contaminated sediments. Dissertation. Wageningen Univ., the Netherlands.

Hassanin, A., K. Breivik, S. Meijer, E. Steinnes, G.O. Thomas, and K.C. Jones. 2004. PBDEs in European background soils: Levels and factors controlling their distribution. Environ. Sci. Technol. 38:738-745.

Hay, A.G., and D.D. Focht. 1998. Cometabolism of DDE by Pseudomonas acidovorans M3GY grown on biphenyl. Appl. Environ. Microbiol. 64:2141-2146.

Houot, S., D. Clergeot, J. Michelin, C. Francou, S. Bourgeois, G. Caria, and H. Ciesielski. 2002. Agronomic value and environmental impacts of urban composts used in agriculture. p. 457-472. In H. Insam et al. (ed.) Microbiology of composting. Int. Conf. Microbiology of Composting, Innsbruck, Austria. 18-20 Oct. 2000. Springer, Berlin.

Howie, B. 1991. Effects of dried wastewater-treatment sludge application on ground-water quality in south Dade County, Florida. USGS/ WRI-91-4135. USGS, Reston, VA.

Huang, H.-J., S.-M. Shiu, and C.-E. Kuo. 2001. Anaerobic biodegradation of DDT residues (DDT, DDD, and DDE) in estuarine sediment. J. Environ. Sci. Health Part B B36:273-288.

Hung, H., and D. Mackay. 1997. A novel and simple model of the uptake of organic chemicals by vegetation from air and soil. Chemosphere 35:959-977.

Hurst, C.J., R.C. Sims, J.L. Sims, D.L. Sorensen, J.E. McLean, and S. Huling. 1996. Polycylic aromatic hydrocarbon biodegradation as a function of oxygen tension in contaminated soil. J. Hazard. Mater. 51:193-208.

Hurst, C.J., R.C. Sims, J.L. Sims, D.L. Sorensen, J.E. McLean, and S. Huling. 1997. Soil gas oxygen tension and pentachlorophenol biodegradation. J. Environ. Eng. 123:364-370.

Kastner, M., M. Streibich, M. Beyrer, H.H. Richnow, and W. Fritsche. 1999. Formation of bound residues during microbial degradation of $\left[{ }^{14} \mathrm{C}\right]$ anthracene. Appl. Environ. Microbiol. 65:1834-1842.

Kaufman. 1983. Fate of toxic organic compounds in land-applied wastes. p. 77-151. In J. Parr (ed.) Land treatment of hazardous wastes. Noyes Data Corp., Park Ridge, NJ.

Kester, J.E., R.L. VanHorn, and N.L. Hampton. 1998. Methodology for conducting screening-level ecological risk assessments for hazardous waste sites. Part 3. Exposure and effects assessment. Int. J. Environ. Pollut. 9:62-89.

Kirchmann, H., and A. Tengsved. 1991. Organic pollutants in sewage sludge. 2. Analysis of barley grains grown on sludge-fertilized soil. Swed. J. Agric. Res. 21:115-119.

Klöpffer, W. 1994. Environmental hazard-assessment of chemicals and products. Environ. Sci. Pollut. Res. Int. 1:108-116.

Kononova, M., T. Nowakowski, and A. Newman. 1966. Soil organic matter. Pergamon Press, London.

Kubatova, A., M. Mutacha, P. Erbanova, C. Vovotny, V. Vlaskova, and V. Sasek. 1998. Investigation into PCB biodegradation using uniformly 14C-labeled dichlorobiphenyl. Isotopes Environ. Health Stud. 34:325-334

Lee, H.-B., and T.E. Peart. 2002. Organic contaminants in Canadian municipal sewage sludge. Part I. Toxic or endocrine-disrupting phenolic compounds. Water Qual. Res. J. Can. 37:681-696.

$\mathrm{Li}, \mathrm{Y}$. 1994. Plant response to ${ }^{14} \mathrm{C}$-labeled 2,2',4,4" tetrachlorobiphenyl and benzo(a)pyrene in a compost-amended soil. Ph.D. thesis. North Carolina State Univ., Raleigh.

Li, H., S. Guangyao, S. Wentao, and X. Ouyong. 2002. Uptake of trifluralin and lindane from water by ryegrass. Chemosphere 48 : 335-341.

Loehr, R., W. Jewell, J. Novak, W. Clarkson, and G. Friedman. 1979. Land application of wastes. Vol. 1 and 2. Van Nostrand Reinhold, New York.

Loehr, R.C., and M.T. Webster. 1997. Changes in toxicity and mobility resulting from bioremediation processes. Biorem. J. 1:149-163.

Lue-Hing, C., R.I. Pietz, T.C. Granato, and D.R. Zenz. 1997. Thirty years of sludge utilization: The Chicago contribution. p. 55-65. In Proc. WEFTEC '97, Water Environment Federation Annual Conf. \& Exposition, 70th, Chicago. 18-22 Oct. 1997. Water Environ. Fed., Alexandria, VA.

McFarlane, C., C. Nolt, C. Wickliff, T. Pfleeger, R. Shimabuku, and
M. McDowell. 1987. The uptake, distribution and metabolism of four organic chemicals by soybean plants and barley roots. Environ. Toxicol. Chem. 6:847-856.

Megharaj, M., S. Hartmans, K. Engesser, and J.H. Thiele. 1998. Recalcitrance of 1,1-dichloro-2,2-bis(p-chlorophenyl) ethylene to degradation $\mathrm{b}$ pure cultures of 1,1-diphenylethylene-degrading aerobic bacteria. Appl. Microbiol. Biotechnol. 49:337-342.

Morrison, D.E., B.K. Robertson, and M. Alexander. 2000. Bioavailability to earthworms of aged DDT, DDE, DDD, and dieldrin in soil. Environ. Sci. Technol. 34:709-713.

Naylor, L.M., and R.C. Loehr. 1982. Priority pollutants in municipal sewage sludge. Part II. BioCycle 23:37-42.

Nellessen, J.E., and J.S. Fletcher. 1993. Assessment of published literature pertaining to the uptake/accumulation, translocation, adhesion, and biotransformation of organic chemicals by vascular plants. Environ. Toxicol. Chem. 12:2045-2052.

Nieman, J.K.C. 2004. Bound residue formation in bioremediated PAH and PCP contaminated soil as an acceptable treatment endpoint. Dissertation. Dep. of Civil and Environ. Eng., Utah State Univ., Logan.

Nieman, J.K.C., R.C. Sims, J.L. Sims, D.L. Sorensen, J.E. McLean, and J.A. Rice. 1999. $\left[{ }^{14} \mathrm{C}\right]$ Pyrene bound residue evaluation using MIBK fractionation method for creosote-contaminated soil. Environ. Sci. Technol. 33:776-781.

O'Connor, G. 1996. Organic compounds in sludge-amended soils and their potential for uptake by crop plants. Sci. Total Environ. 185: 71-81.

Overcash, M., and W. Nutter. 2001. Review of land treatment system design for industries. Nutter, Overcash, and Associates, Athens, GA.

Overcash, M., and D. Pal. 1979. Design of land treatment systems for industrial wastes. Ann Arbor Sci., Ann Arbor, MI.

Paterson, S., D. Mackay, D. Tram, and W.Y. Shiu. 1990. Uptake of organic chemicals by plants: A review of processes, correlations and models. Chemosphere 21:297-331.

Pedersen, J.A., M.A. Yeager, and I.H. Suffet. 2002. Characterization and mass load estimates of organic compounds in agricultural irrigation runoff. Water Sci. Technol. 45:103-110.

Power, J.F., W.A. Dick, R.M. Kashmanian, J.T. Sims, R.J. Wright, M.D. Dawson, and D. Bezdicek (ed.) 2000. Land application of agricultural, industrial, and municipal by-products. SSSA Book Ser. 6. SSSA, Madison, WI.

Quensen, J.F., III, J.M. Tiedje, K.K. Jain, and S.A. Mueller. 2001. Factors controlling the rate of DDE dechlorination to DDMU in Palos Verdes margin sediments under anaerobic conditions. Environ. Sci. Technol. 35:286-291.

Richnow, H.H., E. Annweiler, M. Konig, J.-C. Luth, R. Stegmann, C. Garms, W. Francke, and W. Michaelis. 2000. Tracing the transformation of labeled [1-13C]phenanthrene in a soil bioreactor. Environ. Pollut. 108:91-101.

Richnow, H.H., A. Eschenbach, B. Mahro, M. Kastner, E. Annweiler, R. Seifert, and W. Michaelis. 1999. The formation of nonextractable soil residues: A stable isotope approach. Environ. Sci. Technol. 33:3761-3767.

Richnow, H.H., A. Eschenbach, B. Mahro, R. Seifert, P. Wehrung, P. Albrecht, and W. Michaelis. 1998. The use of ${ }^{13} \mathrm{C}$-labelled polycyclic aromatic hydrocarbons for the analysis of their transformation in soil. Chemosphere 36:2211-2224.

Richnow, H.H., R. Seifert, J. Hefter, M. Link, W. Francke, G. Schaefer, and W. Michaelis. 1997. Organic pollutants associated with macromolecular soil organic matter: Mode of binding. Org. Geochem. 26:745-758.

Roper, J.C., and F.K. Pfaender. 2001. Pyrene and chrysene fate in surface soil and sand microcosms. Environ. Toxicol. Chem. 20:223-230.

Ross, I., S. Sizemore, J. Bowden, and C. Haan. 1978. Effects of soil injection of liquid dairy manure on the quality of surface runoff. Res. Rep. 113. Univ. of Kentucky Water Resour. Res. Inst., Lexington.

Schnabel, W.E., and D.M. White. 2001. The effect of mycorrhizal fungi on the fate of PCBs in two vegetated systems. Int. J. Phytorem. 3:203-220.

Schnitzer, M., and S. Khan. 1972. Humic substances in the environment. Marcel Dekker, New York.

Schroll, R., B. Bierling, G. Cao, U. Doerfler, M. Lahaniati, T. Langenbach, I. Scheunert, and R. Winkler. 1994. Uptake pathways of 
organic chemicals from soil by agricultural plants. Chemosphere 28:297-303.

Schroll, R., and I. Scheunert. 1992. A laboratory system to determine separately the uptake of organic chemicals from soil by plant roots and by leaves after vaporization. Chemosphere 24:97-108.

Senesi, N., and T.M. Miano. 1995. The role of abiotic interactions with humic substances on the environmental impact of organic pollutants. p. 311-335. In P.M. Huang, J. Berthelin, J.-M. Bollag, W.B. McGill, and A.L. Page (ed.) Environmental impact of soil component interactions. Volume I. CRC Press, Boca Raton, FL.

Sharma, J.S.K., K.V. Sadasivam, and J.M. Dave. 1987. DDT degradation by bacteria from activated sludge. Environ. Int. 13:183-190.

Sims, R., and J. Sims. 2003. Landfarming framework for sustainable soil bioremediation. p. 319-334. In The utilization of bioremediation to reduce soil contamination: Problems and solutions. Kluwer Academic Publ., Dordrecht, the Netherlands.

Sims, R.C., and C.K. Abbott. 1993. Evaluation of mechanisms of alteration and humification of PAHs for water quality management. USGS Rep. G-1723. USGS, Reston, VA.

Sims, R.C., and J.L. Sims. 1999. Landfarming of petroleum contaminated soils. p. 767-781. In Bioremediation of contaminated soils. Agron. Monogr. 37. ASA, Madison, WI.

Smith, K.E.C., M. Green, G.O. Thomas, and K.C. Jones. 2001. PAHs on pasture. Environ. Sci. Technol. 35:2141-2150.

Stevens, J.L., G.L. Northcott, G.A. Stern, G.T. Tomy, and K.C. Jones. 2003. PAHs, PCBs, PCNs, organochlorine pesticides, synthetic musks, and polychlorinated n-alkanes in U.K. sewage sludge: Survey results and implications. Environ. Sci. Technol. 37:462-467.

Streebin, L., J. Robertson, A. Callender, L. Doty, and K. Bagawandoss. 1984. Closure evaluation for petroleum residue land treatment. EPA-600/2-84-162. USEPA, Ada, OK.

Strompl, C., and J.H. Thiele. 1997. Comparative fate of DPE, DDE, and PCP under alternating aerobic and anaerobic conditions. Arch. Environ. Contam. Toxicol. 33:350-356.

Symons, B., and R.C. Sims. 1988. Assessing detoxification of a complex hazardous waste using the Microtox bioassay. Arch. Environ. Contam. Toxicol. 17:497-505.

Thiele, J.H., R.S. Simmonds, and B.H. Lawrence. 1999. Recalcitrance of DDE and DPE to cometabolic aerobic biodegradation. Int. J. Environ. Stud. 56:667-688.

Tischler, M.L., C. Pergler, M. Wilson, D. Mabry, and M. Stephenson. 1995. Landfarming of municipal sewage sludge at Oak Ridge, Tennessee. p. 489-495. In R.E. Hinchee et al. (ed.) Applied bioremedia- tion of petroleum hydrocarbons. Papers from the 3rd Int. In Situ and On-Site Bioreclamation Symp., San Diego, CA. April 1995. Battelle Press, Columbus, $\mathrm{OH}$.

Topp, E., I. Scheunert, A. Attar, and F. Korte. 1986. Factors affecting the uptake of carbon-14-labeled organic chemicals by plants from soil. Ecotoxicol. Environ. Saf. 11:219-228.

USEPA. 1982. Retention and transformation of selected pesticides and phosphorous in soil-water systems: A critical review. EPA/ 600/3-82/060. USEPA, Washington, DC.

USEPA. 1986a. Toxic substances control act chemical substances inventory. EPA/560/7-86/003B. USEPA, Washington, DC.

USEPA. 1986b. Field and laboratory evaluation of petroleum land treatment system closure. USEPA, Ada, OK.

USEPA. 1988. Treatment potential for 56 EPA listed hazardous chemicals in soil. EPA/600/6-88-001. USEPA, Ada, OK.

USEPA. 1995. A guide to the biosolids risk assessments for EPA part 503 rule. EPA/832-B-93-005. USEPA, Washington, DC.

USEPA. 1996. Champion International Superfund Site, Libby, Montana: Bioremediation field performance evaluation of the prepared bed land treatment systems. EPA/600/R-95/156. USEPA, Washington, DC.

USEPA. 2002. Statistical support document for the development of round 2 biosolids use or disposal regulations. EPA-822-R-02-034. USEPA, Washington, DC.

Van der Meer, J. 1997. Evolution of novel metabolic pathways for the degradation of chloroaromatic compounds. Antonie van Leeuwenhoek 71:159-178.

Waksman, S. 1938. Humus. Williams \& Williams Co., Baltimore.

Waldman, P. 2003. EPA bans staff from discussing issue of perchlorate pollution. The Wall Street Journal. 28 April, p. A3.

Wang, X., X. Yu, and R. Bartha. 1990. Effect of bioremediation on polycyclic aromatic hydrocarbon residues in soil. Environ. Sci. Technol. 24:1086-1089.

Webber, M.D., and S. Lesage. 1989. Organic contaminants in Canadian municipal sludges. Waste Manage. Res. 7:63-82.

Webber, M.D., and C. Wang. 1995. Industrial organic compounds in selected Canadian soils. Can. J. Soil Sci. 75:513-524.

Wheeler, B. 2003. Evaluating the uptake of nonylphenol and nonylphenol ethoxylates by crested wheatgrass. Thesis. Dep. of Civil and Environ. Eng., Utah State Univ., Logan.

White, J.C., X. Wang, M.P.N. Gent, W. Iannucci-Berger, B.D. Eitzer, N.P. Schultes, M. Arienzo, and M.I. Mattina. 2003. Subspecieslevel variation on the phytoextraction of weathered p,p'-DDE by Cucurbita pepo. Environ. Sci. Technol. 37:4368-4373. 